\title{
DU PIRMINIAI NAVIKAI PACIENTO GALVOS SMEGENYSE: GLIOBLASTOMA IR MENINGIOMA. KLINIKINIS ATVEJIS
}

\author{
Danius Liutkus', Arnas Staškevičius', Darius Šilkūnas', Valdas Gasilionis² \\ ${ }^{1}$ Klaipédos universitetinès ligoninès Neurochirurgijos klinika, \\ ${ }^{2}$ Klaipèdos universitetinès ligoninès Patologijos skyrius
}

\begin{abstract}
Raktažodžiai: glioblastoma, meningioma, du pirminiai galvos smegenų navikai.

Santrauka

Du pirminiai, skirtingos histologinès struktūros navikai, susiformavę vieno paciento galvos smegenyse - labai reta neurochirurginè patologija. Straipsnyje pristatomas 64 metų vyro klinikinis atvejis, kai šiam pacientui buvo nustatyti du skirtingos histologinès struktūros pirminiai galvos smegenų navikai - meningioma ir glioblastoma. Abu navikai buvo sékmingai pašalinti per vieną chirurginę intervenciją ir vietą. Vèliau pacientas nusiųstas pas kitus specialistus, kad jam būtų atlikta chemoterapija ir radioterapija. Straipsnyje apžvelgiama kitų autorių patirtis ir galimos dviejų skirtingos histologinès struktūros navikų susiformavimo priežastys. Sėkmingam tokių navikų gydymui reikalingas visapusiškas radiologinis ištyrimas, didelè neurochirurgijos praktikos patirtis ir patikima multidisciplininè komanda.
\end{abstract}

\section{Ivadas}

Du skirtingos histologinès struktūros, pirminiai galvos smegenų navikai, susiformavę vienam pacientui - labai retai pasitaikantis atvejis neurochirurgijos praktikoje. Dažniausiai šie navikai nustatomi ligoniams, turintiems genetinių susirgimų, tokių kaip neurofibromatozė ar tuberozinè sklerozé. Taip pat minèti navikai gali būti antriniai, atsiradę po spindulinio galvos smegenu gydymo arba chemoterapijos [1]. Iki šiol mokslinèje literatūroje aprašyti tik pavieniai atvejai, kai du navikai nustatyti, prieš tai netaikius minèto gydymo, arba gretutiné patologija iš viso nenustatyta. Pagal JAV onkologinių ligų registrą, meningioma yra dažniausiai pasitaikantis pirminis galvos smegenų navikas (36,3 proc.), antras pagal dažnumą - glioblastoma (14,9 proc.) [2]. Pirmaji atveji, kai pacientui nustatytos ir meningioma, ir glioblastoma, $1938 \mathrm{~m}$. aprašè H. Cushing ir L. Eisenhahardt [3]. Tačiau atsitikimai, kai šie navikai susiformuoja vienas šalia kito - labai reti.

Šiame straipsnyje pristatomas klinikinis atvejis, kai tokie skirtingos histologijos navikai - meningioma ir glioblastoma - buvo nustatyti susiformavę vienas šalia kito.

\section{Klinikinio atvejo aprašymas}

Vyras, kuriam 64 m., atvyko ị Klaipedos universitetinès ligoninès Neurochirurgijos kliniką dèl pirmą kartą jo gyvenime įvykusio traukulių priepuolio; atvykęs skundèsi galvos skausmu. Artimujų teigimu, maždaug prieš 3 mèn. pasikeitè paciento elgesys, dèl ko jis šeimos gydytojo buvo nusiųstas konsultuotis pas psichiatrą. Per priepuoli generalizuotų traukulių nepastebèta, tačiau buvo nusilpusios kairiosios pusès galūnès. Pacientui paskyrus gydymą apskrities ligoninèje, minèta simptomatika regresavo. Šioje ligonineje atliktoje galvos kompiuterinèje tomogramoje (KT) matyti navikui būdingi pakitimai su plačia aplinkine edema ir masès efektu bei vidurio linijos struktūrų dislokacija. Ką tik atvykusio ligonio būklè apibūdinta taip: Karnovskio indeksas siekia 60 proc., horizontalus nistagmas abejose pusèse, kituose galviniuose nervuose patologijos nepastebèta; simetriški galūnių refleksai ir jèga, patologinių refleksų nematyti; atsistojęs Rombergo poza, pacientas nestabilus, koordinacinius mėginius atlieka su paklaida; meninginiai simptomai neigiami.

Radiologinių tyrimų rezultatai: atliktas galvos magnetinio rezonanso tyrimas (MRT), pritaikius intraveninį kontrastavimą (1-3 pav.). Galvos smegenų dešinèje kaktinejje skiltyje pastebima masyvi, apie $7,4 \times 6,5 \mathrm{~cm}$ dydžio navikinè infiltracija, pereinanti ị priešingą smegenų pusrutuli per didžiają smegenų jungtị. Struktūra heterogeniška. Centre plati nekrozės zona, matyti aplinkinès edemos požymiai. Dešinejje kaktinejje srityje ties galvos smegenų pjautuvu pastebètas $2 \times 2,2 \mathrm{~cm}$ dydžio darinys, kuris tolygiai kaupia kontrastinę medžiagą ir yra hiperintensinis T2 ir hipointensinis $\mathrm{T} 1$ sekose.

Ligos eigos aprašymas: pacientas operuotas, pašalintas 7,5×6,5×4 cm dydžio navikas, neturintis aiškių ribų, su 


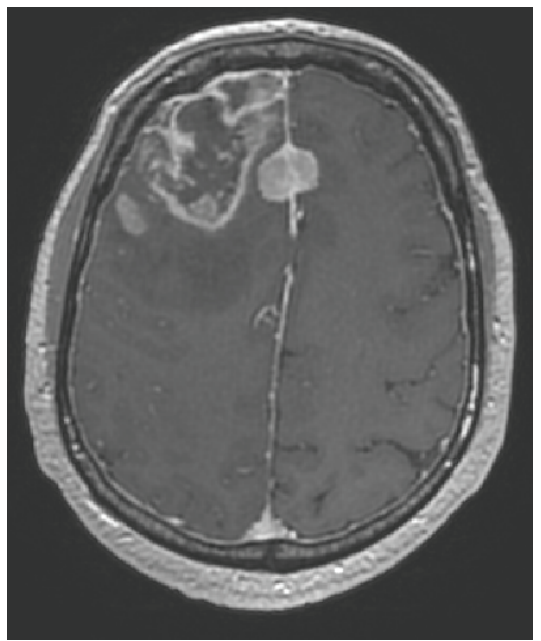

1 pav. MRT T1 su kontrastine medžiaga, aksialinis pjūvis.

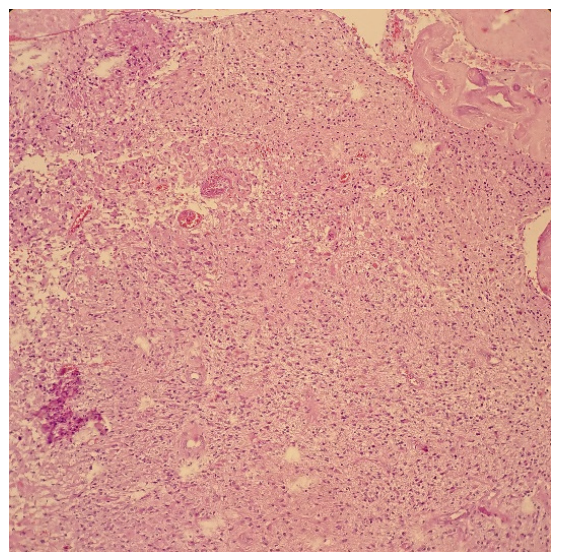

4 pav. Glioblastoma.

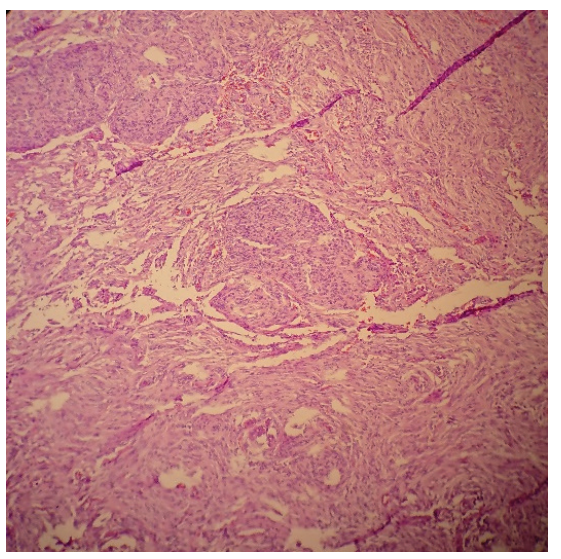

5 pav. Pereinamoji meningioma.

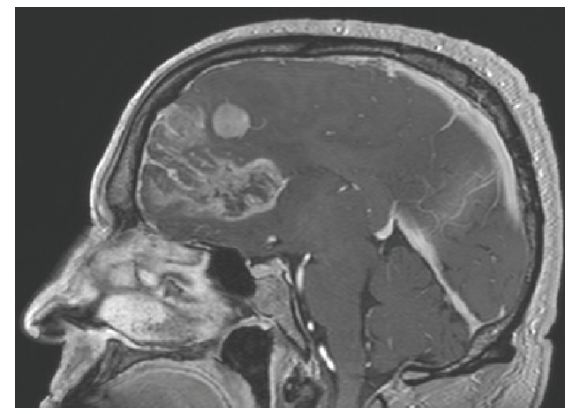

2 pav. MRT T1 su kontrastine medžiaga, sagitalinis pjūvis.

gausiomis nekrozės zonomis ir trombuotomis kraujagyslèmis. Chirurginiu būdu per tą pačią i̇ejimo vietą vizualizuotas kitas, nuo galvos smegenų pjautuvo augantis navikas, kuris radikaliai pašalintas, rezekuojant smegenų pjautuvo dali. Histologinio tyrimo rezultatai: pirmasis navikas - IV laipsnio glioblastoma pagal Pasaulio sveikatos organizacijos (PSO) kvalifikaciją, IDH1/2 mutacija nenustatyta. (4 pav.); antrasis - PSO I laipsnio pereinamoji meningioma (5 pav.).

Tolesne paciento gydymo taktika aptarta per Klaipèdos universitetinès ligoninès multidisciplininį konsiliumą, ligonis nusiųstas atlikti chemoterapiją ir radioterapiją.

\section{Rezultatų aptarimas}

Atvejai, kai dauginiai pirminiai navikai nustatomi vienam ligoniui, nėra labai dažni ir sudaro apie 0,3 proc. visų pirmą kartą diagnozuotų galvos smegenų navikų atvejų [1]. Kadangi meningiomos ir glialiniai navikai yra dažniausi pirminiai smegenų navikai, kartais abiejų tipų dariniai nustatomi vienam ligoniui. Tiek meningioma, tiek glioblastoma dažniausiai aptinkamos 50-60 m. amžiaus asmenų smegenyse [4,5]. Šiame straipsnyje aprašytu atveju, du šalia susiformavę navikai nustatyti $64 \mathrm{~m}$. amžiaus vyrui. Tiksli ligos eigos priežastis nėra žinoma. Tam tikruose šaltiniuose užfiksuota, kad keli pirminiai navikai yra nustatyti pacientams, turintiems tokị genetinị susirgimą, kaip neurofibromatozė ar tuberozinè sklerozé, arba ligoniams po spindulinės terapijos, chirurginių operacijų. Šiuo metu literatūroje anglų kalba galima rasti tik kiek daugiau nei 70 atvejų, kai vienam pacientui nustatomi glialinis navikas ir meningioma vienu metu [6]. Tačiau ypač retai pasitaiko, kad abu šie navikai būtų vienas šalia kito. Šio reiškinio priežastis nèra aiški, manoma, kad tokia patologija gali būti susijusi su keliais onkogenetiniais faktoriais. K. Suzuki ir kt. nurodo, kad aptariamam reiškiniui įtakos gali turèti p53 navikinis baltymas ir keletas kitų augimo faktorių receptoriu [1]. Taip pat manoma, kad prie šių veiksnių gali prisidèti tai, jog vienos histologinès struktūros navikas gali iššaukti kito naviko atsiradimą, kai aplink meningiomą esančios smegenų glijos ląstelès transformuojasi į naviką [7-9]. Zhen Zhang ir kt. taip pat mano, kad meningioma, ypač meningotelinè ir fibrozine, pati gali veikti aplinkinès smegenų glijos neoplastinius procesus [10]. Kiti autoriai iškelia hipotezę, kad ilgametis meningiomos spaudimas ị aplinkinius smegenų audinius gali stimuliuoti astrocitų aktivaciją ir proliferaciją, 
sukeldamas smegenų glijos ląstelių mutacijas ir tolimesnę transformaciją i glioblastomą [11]. J. Vaquaero ir kt. aprašè atvejį, kai tarp navikų pastebètos mišrios, abiem navikams būdingos sritys, kas leidžia teigti, kad vienas navikas gali indukuoti kito naviko augimą ar supiktybejimą [12]. Dalis autorių mano, kad glialinis navikas gali sukelti voratinklinio dangalo ląstelių navikinę transformaciją i meningiomą [13]. Literatūroje dažnai pateikiami atvejai, kai kitokios histologinès struktūros navikai atsiranda po sunkios galvos smegenų traumos arba spindulinès terapijos [14-17]. Šiame straipsnyje aptariamu atveju, ligonis nebuvo patyręs sunkios galvos smegenų traumos, prieš navikų atsiradimą jam netaikyta spindulinè terapija. Per operaciją tarp navikų buvo matomos aiškios ribos, skirtinga kraujotaka ir navikinè struktūra. Tačiau negalima atmesti hipotezès, kad pirminè meningioma galèjo išprovokuoti smegenų glijos ląstelių navikinę transformaciją ir naviko susiformavimą.

\section{Išvados}

Du greta susiformavę pirminiai galvos smegenų navikai yra retai sutinkama patologija neurochirurginèje praktikoje. Jos diagnostika ir gydymas vykdomas griežtai pagal multidisciplininès komandos nutarimus. Chirurginiam gydymui ir operacijos planavimui būtinas visapusiškas radiologinis ištyrimas. Per pooperacini periodą, kai gauti patologijos tyrimo rezultatai, Klaipèdos universitetineje ligoninejje paciento būklè aptariama per multidisciplininị pasitarimą, numatoma tolesnè gydymo taktika. Dažniausiai tokiems ligoniams skiriama pooperacinis spindulinis gydymas ir chemoterapija.

\section{Literatūra}

1. Suzuki K, Momota H, Tonooka A, Noguchi H, Yamamoto K, Wanibuchi M, Minamida Y, Hasegawa T, Houkin K. Glioblastoma simultaneously present with adjacent meningioma: case report and review of the literature. J Neurooncol 2010;99:147-153. https://doi.org/10.1007/s11060-009-0109-9

2. Ostrom QT, Gittleman H, Liao P, Vecchione-Koval T, Wolinsky Y, Kruchko C, Barnholtz-Sloan JS. CBTRUS statistical report: primary brain and other central nervous system tumors diagnosed in the United States in 2010-2014. Neuro Oncol 2017 Nov;19(Suppl 5):v1-v88.

https://doi.org/10.1093/neuonc/nox158

3. Cushing H, Eisenhardt L. Meningiomas: their classification, regional behaviour, life history, and surgical end results. Charles C Thomas (Springfield, IL). 1938;506 \pm 507 .

4. Baldi I, Engelhardt J, Bonnet C, Bauchet L, Berteaud E,,Grüber A, Loiseau H. Epidemiology of meningiomas. Neurochirurgie 2018 Mar;64(1):5-14. https://doi.org/10.1016/j.neuchi.2014.05.006

5. Louis DN, Perry A, Reifenberger G. et al. The 2016 World Health Organization classification of tumors of the central nervous system: a summary. Acta Neuropathol 2016;131(6).

https://doi.org/10.1007/s00401-016-1545-1

6. Tunthanathip T, Kanjanapradit K, Ratanalert S, Phuenpathom N, Oearsakul T, Kaewborisutsakul A. Multiple, primary brain tumors with diverse origins and different localizations: case series and review of the literature. J Neurosci Rural Pract 2018 Oct-Dec;9(4):593-607. https://doi.org/10.4103/jnrp.jnrp_82_18

7. Lee EJ, Chang CH, Wang LC, Hung YC, Chen HH. Two primary brain tumors, meningioma and glioblastoma multiforme, in opposite hemispheres of the same patient. J Clin Neurosci 2002;9:589-591.

https://doi.org/10.1054/jocn.2002.1086

8. Prayson RA, Chowdhary S, Woodhouse S, Hanson M, Nair S. Collision of a syncytial meningioma and malignant astrocytoma. Ann Diagn Pathol 2002;6:44-48.

https://doi.org/10.1053/adpa.2002.30612

9. Buccoliero AM, Taddei GL, Caldarella A, Mennonna P, Ammannati F, Taddei A, Mariotti F. Meningioma-primary brain lymphoma association. Neuropathology 2004;24:336-340.

https://doi.org/10.1111/j.1440-1789.2004.00570.x

10. .Zhang Z, Yang Y, Zhang K, Zhuang J, Shao F, Liu H, Xing $\mathrm{Y}, \mathrm{Xu}$ S. Collision tumor of glioblastoma and meningioma: case report and literature review. World Neurosurg 2018 Sep;117:137-141.

https://doi.org/10.1016/j.wneu.2018.05.246

11. Pereira EA, Dabbous B, Qureshi HU, Ansorge O, Bojanic S. Rapid development of glioblastoma at the site of atypical meningioma resection. Br J Neurosurg 2010 Aug;24(4):471-473. https://doi.org/10.3109/02688691003710510

12. Vaquero J, Coca S, Martínez R, Jiménez C. Convexity meningioma and glioblastoma in collision. Surg Neurol 1990;33:139141. https://doi.org/10.1016/0090-3019(90)90023-I

13. Zhang D, Yu J, Guo Y, Zhao S, Shao G, Huang H. An intraventricular meningioma and recurrent astrocytoma collision tumor: a case report and literature review. World J Surg Oncol 2015 Feb 12;13:37.

https://doi.org/10.1186/s12957-015-0436-6

14. Moshkin O, Scheithauer BW, Syro LV, Velasquez A, Horvath E, Kovacs K. Collision tumors of the sella: craniopharyngioma and silent pituitary adenoma subtype 3: case report. Endocr Pathol 2009;20:50-55.

https://doi.org/10.1007/s12022-009-9065-3

15. Preston-Martin S, Pogoda JM, Schlehofer B, Blettner M, Howe GR, Ryan P. et al. An international case-control study of adult glioma and meningioma: the role of head trauma. Int J Epidemiol 1998;27:579-586.

https://doi.org/10.1093/ije/27.4.579

16. Pereira EA, Dabbous B, Qureshi HU, Ansorge O, Bojanic S. Rapid development of glioblastoma at the site of atypical me- 
ningioma resection. Br J Neurosurg 2010;24:471-473.

https://doi.org/10.3109/02688691003710510

17. Campbell RM, Mader RD, Dufresne Jr RG. Meningiomas after medulloblastoma irradiation treatment in a patient with basal cell nevus syndrome. J Am Acad Dermatol 2005;53:S256-S259. https://doi.org/10.1016/j.jaad.2005.03.033

18. Martínez-Lage J, Martínez-Pérez M, Poza M, Ros de San Pedro J. Meningiomas after radiation-therapy for benign astrocytomas. Neurocirugia (Astur) 2005;16:266-270.

https://doi.org/10.1016/S1130-1473(05)70410-3

\section{CLINICAL CASE OF TWO PRIMARY TUMORS - GLIOBLASTOMA AND MENINGIOMA IN THE ENCEPHALON OF ONE PATIENT}

D. Liutkus, A. Staškevičius, D. Šilkūnas, V. Gasilionis

Keywords: glioblastoma, meningioma, double tumors, primary tumors.
Summary

Two primary encephalon tumors having different histological characteristics in one patient is a very rare neurosurgical pathology. The article presents the clinical case of the 64-year-old man who had two primary encephalon tumors - meningioma and glioblastoma. Both tumors were successfully removed during one surgical approach. Afterwards, the patient was referred for the chemotherapy and radiotherapy. The article reviews the experience of other authors and the possible causes of the formation of these two tumors which have different histological structure. Successful treatment of such tumors requires complete radiological examination, experience in neurosurgical practice, and a reliable multidisciplinary team.

Correspondence to: daniusliu@gmail.com

Gauta 2019-10-08 